\title{
EVALUATION OF TEN MAIZE HYBRIDS FOR SILAGE YIELD AND QUALITY
}

\author{
Abdel Gawad, M.A.S.'; Hoda Kh. A. El Makser ${ }^{2}$ and \\ M. M. M. Hassan ${ }^{2}$ \\ 1- Forage Crops Res. Dep., Field Crops Res. Inst., A.R.C.,Giza, Egypt. \\ 2- Maize Res. Dep., Field Crops Research Institute, A.R.C., Giza, Egypt.
}

\begin{abstract}
A field experiment was carried out at Gemmeiza Research station during the two successive seasons; 2005 and 2006 to evaluate ten maize hybrids for silage yield, quality, and nutrient contents. The experiment included three single cross (SC10, SC123, SC155) and seven three-way cross hybrids TWC310, TWC311 TWC320 TWC321, TWC322, TWC323, and TWC324 . Significant differences (P0.05) were found among the tested hybrids; The highest fresh silage yield was recorded for hybrid SC10 in both seasons, (23.94 and 25.31 tons / faddan, respectively). Hybrids TWC320 and TWC324 possessed the highest dry matter (DM) yield in the two seasons (6.65 and $\left.7.51 \mathrm{t} \mathrm{fad}^{-1}\right)$, respectively. It was evident that the number of days to $50 \%$ tasseling, combined over the two seasons, ranged between 59 and 66 for SC155 and SC123 hybrids respectively . Respecting to $50 \%$ sillking, the combined analysis showed 8.25 days difference between the earliest ( SC155) and the lastest hybrid (SC10). Results at silage maturity stage, which was assessed on the DM basis ranged between 283 (SC123) and 340 (TWC324) $\mathrm{g} \mathrm{Kg}^{-1}$. Data showed that crude protein \% ranged between $5.9 \%$ (TWC323) to 8.2\% (TWC310), CF between 22.4 (TWC320) to 29.5 (TWC), EE between 1.32 (TWC310) to 2.97 (SC10), NFE between 55.1 (TWC324) to 60.1 (TWC320), Ash between 6.3 (TWC322) to 8.5 (TWC311), DCP between 2.03 (TWC323) to 4.15 (TWC310), and TDN between 62.1 (TWC323) to 63.9 (TWC311). For silage quality, $\mathrm{pH}$ ranged from 3.6 (TWC311) to 4.05 (SC155), VFAs from 1.46 (TWC311) to 2.44 (SC155), Lactic acid from 3.78 (SC155) to 5.25 (SC10), and $\mathrm{NH}_{3} \mathrm{~N} \%$ from 4.08 (SC123) to 6.88 (SC155). These data indicate that all hybrids are suitable for silage production.

Keywords: Hybrid Maize Silage quality, Quantity, Nutrient composition
\end{abstract}

\section{INTRODUCTION}

Maize is one of the most important cereal crops in Egypt. About 1.7 million faddan are cultivated annually with maize. Therefore, preserving amounts of whole maize plants as silage help in reducing feed shortage problem (Mahmoud et al.1992). Utilization of maize silage has increased rapidly as green forage for dairy cattle. This increase can be attributed to the relatively high-energy yield of maize crop and the facility of using mechanization with which the whole plant can be ensiled to provide highly palatable source of energy and high quality forage (Mohamed et al.1999) .

Hybrid selection is a key to improve forage quality for optimum animal output. Historically, there has been significant genetic variabilities among maize hybrids for many forage quality components.

Maize hybrids, traditionally, have been selected for grain yield production assuming that high yield of whole plant silage would be attained. However hybrids selected for high grain yield may not be the highest yielding hybrids for whole plant silage, also this selection strategy ignores differences in the nutritive value of whole plant maize silage related to maize genetics. 
For a long time breeders and farmers relied on the assumption that a high yielding grain maize variety would be the most suitable for silage production. Genetic variations in maize forage digestibility have been clearly proved (Allen et al. 1990; and Wolf et al. 1993). Moreover Differences in Crude fiber (CF), Crude protein (CP), and cell wall digestibility, depend on the plant genotype (Roth et al., 1970).

Until recently, it was generally accepted that a good silage hybrid is that possessing a good grain, based on the assumption that silage nutritive value is dominated by the grain component (Andrews et al., 2000). In the past, most differences in maize silage and its digestibility were considered to be related to maturity, and differences between hybrids were of less importance ( Kuehn et al., 1999) . Ghanen et al. (2000). Found appreciable differences in fresh and DM yieds of stovers in 5 maize hybrids. Bendary et al. (2001) reported significant differences in yield of whole plants, DM produced as silage and relative plant parts among 5 single cross, 4 threeway crosses and one variety of maize. They attributed these differences to several factors including variety, time of planting, plant density. Agricultural management and stage of maturity at time of harvest. Ma et al.(2006) reported that rapid dry- dawn rate favors grain production, while gradual decline in whole plant moisture (slower dry- down rate) favors silage varieties. This distinct characteristic refracted in the changes in DM accumulation. Therefore, the objectives of this study were:

1-Evaluation of maize hybrids for whole plant silage yield and quality, to determine the best hybrids for silage made from the whole maize plant.

2-Determination of the variation in chemical composition, quality, and nutritive value.

\section{MATERIALS AND METHODS}

A field experiment was conducted at Gemmiza. Res. Stn., Egypt in 2005 and 2006 seasons to evaluate ten maize hybrids for fresh and dry silage yields and quality. The evaluated materials involved three single crosses (SC 10, SC 123, SC 155, and seven three - way crosses (TWC 310 , TWC 311, TWC 320, TWC 321, TWC 322, TWC 323, and TWC 324) were used. Soil samples were taken before planting at $(0-30 \mathrm{~cm})$ depth and were analyzed for Physical and chemical analysis.(Table 1).

The randomized complete block design with four replications was used. Planting carried out on May, $19^{\text {th }}$ in 2005 , and May, $2^{\text {nd }}$ in 2006 . Preceding crop was wheat in both seasons. The experimental plot consisted of four rows $6 \mathrm{~m}$ in length, $70 \mathrm{~cm}$ in width and hills spaced at $30 \mathrm{~cm}$ within the row, giving a plant density of 21000 plants/ fad. All cultural practices for maize production were applied as recommended. Nitrogen fertilizer(120 kg N/fad) was added at three equal doses; just before the first, second and the third irrigations. Number of days from planting to $50 \%$ tasseling and silking were counted. At harvest, a random sample of ten guarded plants from each plot was used to estimate plant height $(\mathrm{cm})$ and ear height $(\mathrm{cm})$. The first and fourth row in each plot were considered guarded rows, whereas all plants of the $2^{\text {nd }}$ and $3^{\text {rd }}$ rows were cut at soil surface and weighed at 100 days from planting. 
Plants were chopped for making silage. Samples of $0.5 \mathrm{~kg}$ were taken from each hybrid to estimate dry matter (DM). Other samples were ensilaged in plastic bags (under anaerobic conditions) for 35 days. After that silage samples of the second season only were subjected to analysis at the forage lab, Giza Res Stn. to determine crude protein (CP), crude fiber (CF),ether extract (EE) and ash, as well as the fermentation characters $(\mathrm{pH}$, Lactic acid ,total volatile fatty acids (TVFAs) and nitrogen ammonia $\left(\mathrm{Nh}_{3}-\mathrm{N}\right.$ $\%$ in total N) according to A.O.A.C (1990).

Digestible crude protein (DCP), and total digestible nutrients (TDN) were calculated according to equations of Church (1979) as follows: DCP $=\mathrm{CP} \times$ 0.929-3.48, TDN = 72.1-(CF X 0.34). Recorded data were statistically analyzed using MSTAT C computer program Ver. (4) (1986) .

Homogeneity of variances was tested for the two seasons using Bartlett's test according to Gomez and Gomez (1984). The test was significant for all traits, except for fresh yield, dry yield, days to $50 \%$ silking, and plant height, thus, data of both seasons were combined for only these traits.

Table 1: Physical and chemical properties of the soil at the experimental site.

\begin{tabular}{|c|c|c|c|c|c|}
\hline \multicolumn{7}{|c|}{ Physical analysis } \\
\hline Year & $\begin{array}{c}\text { Coarse Sand } \\
\%\end{array}$ & $\begin{array}{c}\text { Fine Sand } \\
\%\end{array}$ & $\begin{array}{c}\text { Silt } \\
\%\end{array}$ & $\begin{array}{c}\text { Clay } \\
\%\end{array}$ & Texture \\
\hline 2005 & 2.80 & 23.21 & 22.94 & 52.15 & Clay \\
\hline 2006 & 2.70 & 22.11 & 23.19 & 52.00 & Clay \\
\hline \multicolumn{7}{|c|}{ Chemical analysis } \\
\hline \multicolumn{7}{|c|}{$\begin{array}{c}\text { Available N } \\
(\text { ppm })\end{array}$} & $\begin{array}{c}\text { Available P } \\
(\text { ppm })\end{array}$ & $\begin{array}{c}\text { Available K } \\
(\text { ppm })\end{array}$ & pH & $\begin{array}{c}\text { EC m. mohs } \\
\text { /gm }\end{array}$ \\
\hline 2005 & 130.5 & 11.6 & 290.3 & 8.00 & 0.93 \\
\hline 2006 & 125.5 & 12.7 & 291.5 & 7.8 & 1.05 \\
\hline
\end{tabular}

\section{RESULTS AND DISCUSSION}

\section{Fresh and dry matter yields}

Significant differences were observed among the tested ten hybrids . Fresh silage yield of SC 10 was superior to other hybrids in both seasons (Table 2). TWC 320 had the lowest fresh yield in 2005 season (17.94 t / fad), while SC155 had the lowest fresh yield in 2006 season ( $19.81 \mathrm{t} / \mathrm{fad}$ ). On the other hand, TWC 321 had the highest dry matter yield in 2005 season (6.650 t / fad) followed by SC155 and SC10 (6.537 and 6.272 t / fad, respectively). Meanwhile, TWC 324 was superior in 2006 season followed by SC10 and TWC 311 (7.507, 7.300, and $7.145 \mathrm{t} / \mathrm{fad}$, respectively). The two , hybrids TWC 320 and SC 155 were associated with the lowest DM yield in 2005 and 2006, respectively.

Differences in fresh and dry yields among the tested hybrids may be attributed to genetic variability, stages of maturity and harvesting time. These results agreed with those obtained by Ghanen et al. 2000 and Bendary et al. (2001) Differences in fresh and dry silage yields may have resulted also from the differences of whole plant moisture content at time of harvest Ma et al. (2006.) 
Abdel Gawad, M.A.S. et al.

Table 2: Fresh and dry matter yields (ton/fad), of the ten maize hybrids .

\begin{tabular}{|c|c|c|c|c|c|c|}
\hline \multirow{2}{*}{ Hyb. } & \multicolumn{2}{|c|}{ Traits } & $\mathbf{2 0 0 5 h}$ silage yield (t/fad) & \multicolumn{3}{c|}{ Dry silage yield (t/fad) } \\
\cline { 2 - 7 } & $\mathbf{2 0 0 5}$ & $\mathbf{2 0 0 6}$ & Comb & $\mathbf{2 0 0 5}$ & $\mathbf{2 0 0 6}$ & Comb. \\
\hline SC 10 & 23.938 & 25.312 & 24.635 & 6.272 & 7.300 & 6.786 \\
\hline SC 123 & 19.063 & 22.437 & 20.750 & 5.240 & 6.347 & 5.794 \\
\hline SC 155 & 20.088 & 19.812 & 19.950 & 6.537 & 6.065 & 6.301 \\
\hline TWC310 & 21.188 & 20.875 & 21.030 & 5.185 & 6.275 & 5.730 \\
\hline TWC311 & 21.625 & 21.875 & 21.750 & 5.432 & 7.145 & 6.289 \\
\hline TWC320 & 17.938 & 20.625 & 19.282 & 4.745 & 6.582 & 5.664 \\
\hline TWC321 & 21.125 & 22.187 & 21.656 & 6.650 & 6.625 & 6.638 \\
\hline TWC322 & 22.050 & 21.312 & 21.681 & 5.822 & 6.812 & 6.317 \\
\hline TWC323 & 22.188 & 22.875 & 22.032 & 5.945 & 6.535 & 6.240 \\
\hline TWC324 & 20.563 & 22.062 & 21.313 & 5.395 & 7.507 & 6.451 \\
\hline CV \% & 9.63 & 4.36 & 7.360 & 10.080 & 15.92 & 13.82 \\
\hline LSD 0.05 & 2.93 & 1.398 & 1.584 & 0.836 & 1.552 & 0.861 \\
\hline
\end{tabular}

\section{Days to $\mathbf{5 0} \%$ tasseling and silking, plant and ear heights}

Results in Table (3) show that there were significant differences among the ten tested hybrids in number of days to $50 \%$ tasseling. Combined analysis over the two seasons ranged from 59.13 for SC 155 to 66.13 days for SC 123. In general, SC 123 and SC 10 were the latest hybrids. Hybrids TWC 310 , TWC 311 , TWC 320 , TWC 321, TWC 323, and TWC 324 were intermediate, while SC 155 and TWC 322 were the earliest hybrids. Number of days to $50 \%$ silking ranged from 57.25 for SC155 to 63.75 days for SC125 in 2005 and from 62 for SC155 to 73.5 days for SC10 in 2006 . In general SC123 and SC10 were the latest hybrids in 2005 and 2006 respectively, while SC155 was the earliest hybrids over the two seasons. Nofal et al. (2005). Reported that 8 maize hybrids differed by 4.3 and 5.3 days for number of days to $50 \%$ tassling and by 4.5 and 4.8 days for number of days to $50 \%$ silting in the first and second year of their study, respectively. Ma et al. (2006), also found 7 days difference in number of days to so silking among 4 maize hybrids.

Plant and ear heights of the different hybrids varied significantly. Plant height ranged from 224 to $264.75 \mathrm{~cm}$ in 2005 and from 246.25 to $273.5 \mathrm{~cm}$ in 2006. SC 10 was the tallest hybrid followed by TWC 322 then SC 155, which was the shortest hybrid in 2005 season. In contrast, TWC 324 was the tallest hybrid followed by TWC 320 , while TWC 311 was the shortest hybrid in 2006 season. Ear height ranged from 126.25 (SC 123) to $157.38 \mathrm{~cm}$ (TWC 310) combined over both years. These results are mainly due to differences in the genetical make up of the evaluated hybrids. Nofal et al. (2005) found that plant height of 8 maize hybrids differed by 23 and $34 \mathrm{~cm}$ and ear height differed by 14 and $8 \mathrm{~cm}$ in the first and second year, respectively. However Karvchenko et al., (2005) attributed each difference to mostly environmental conditions rather than the genetical make up. 
J. Agric. Sci. Mansoura Univ., 34 (4), April, 2009

3

3299 
Chemical composition and feeding value .

Data presented in Table (4) Showed that dry matter (DM) percentage was significantly different among the ten hybrids, ranged between $28.29 \%$ to $34.03 \%$ for SC 123 and TWC 324, respectively. These values are in accordance to those reported by Ghanem et al 2000 (25.32- 29.88\%) and Bendary et al. 2001 (25.47- 43-69\%). Bal et al (1997) pointed out that moisture contents were $69.9,67.6,64.9$, and $58.0 \%$ for silages from maize harvested at early dent, quarter milk line, two- thirds milk line and black layer stages, respectively. The optimum stage for maize that was ensiled was twothirds milk line, with some flexibility between quarter and two- thirds milk line. Ma et al., (2006) reported that the ideal silage moisture content of 62 to $70 \%$ was achieved between 40 and 50 days after silking, where these moisture levels were achieved depending on the hybrids and the growing season. Dalal (1989) mentioned differences in DM due to delayed maturity.

Table 4: Percentage of chemical analysis of ten maize hybrids in 2006 season

\begin{tabular}{|c|c|c|c|c|c|c|c|c|c|}
\hline $\begin{array}{r}\text { Traits } \\
\text { Hyb . }\end{array}$ & $\begin{array}{c}\text { DM } \\
\%\end{array}$ & $\begin{array}{c}\text { OM } \\
\%\end{array}$ & CP $\%$ & $\begin{array}{c}\text { CF } \\
\%\end{array}$ & $\begin{array}{c}\text { EE } \\
\%\end{array}$ & NFE \% & $\begin{array}{c}\text { Ash } \\
\%\end{array}$ & DCP \% & TDN \% \\
\hline SC 10 & 28.84 & 91.8 & 7.18 & 24.24 & 2.97 & 57.41 & 8.21 & 3.19 & 63.86 \\
\hline SC123 & 28.29 & 93.16 & 6.83 & 24.64 & 2.02 & 59.67 & 6.84 & 2.87 & 63.72 \\
\hline SC155 & 30.61 & 92.65 & 6.72 & 25.98 & 2.00 & 58.05 & 7.35 & 2.76 & 63.30 \\
\hline TWC310 & 30.06 & 92.25 & 8.21 & 25.81 & 1.32 & 56.92 & 7.75 & 4.15 & 63.32 \\
\hline TWC311 & 32.66 & 91.56 & 7.90 & 25.00 & 2.08 & 56.58 & 8.45 & 3.86 & 63.9 \\
\hline TWC320 & 31.91 & 92.22 & 6.96 & 22.44 & 2.76 & 60.07 & 7.79 & 2.98 & 64.48 \\
\hline TWC321 & 29.86 & 92.65 & 6.23 & 26.82 & 1.66 & 57.94 & 7.35 & 2.31 & 62.98 \\
\hline TWC322 & 31.96 & 93.67 & 7.23 & 26.53 & 2.46 & 57.45 & 6.34 & 3.24 & 63.08 \\
\hline TWC323 & 28.57 & 92.78 & 5.93 & 29.50 & 2.03 & 55.32 & 7.23 & 2.03 & 62.07 \\
\hline TWC324 & 34.03 & 93.12 & 7.27 & 24.47 & 2.24 & 55.14 & 6.88 & 3.28 & 63.78 \\
\hline Mean & 30.86 & 92.58 & 7.04 & 25.53 & 2.15 & 57.85 & 7.43 & 3.06 & 63.45 \\
\hline CV \% & 8.9 & 0.7 & 7.1 & 2.4 & 9.6 & 1.4 & 8.7 & 10.9 & 10.3 \\
\hline LSD 0.05 & 1.85 & NS & 0.81 & 1.37 & 0.46 & 1.82 & NS & 0.76 & NS \\
\hline
\end{tabular}

No significant differences were detected among maize hybrids regarding organic matter (OM) content. On the other hand crude protein (CP) content was significantly different among the tested hybrids, and ranged from $5.93 \%$ (TWC 323) to $8.21 \%$ (TWC 310). Crude protein was declined with increasing maturities, Sheperd and Kung (1996). Crude fiber (CF) content varied between 22.44 to $29.50 \%$ for TWC 320 and TWC 323, respectively. Ether extract (EE) percentage ranged from 1.32 to $2.97 \%$ for TWC 310 and SC 10, respectively. Means of nitrogen free extract (NFE) were significantly different among the ten tested hybrids, and ranged from 55.14 to 60.07 for TWC 324 and TWC 320, respectively. Total ash percentage ranged from 6.34 to $8.45 \%$ for TWC 322 and TWC 311, respectively. No significant differences were observed among maize hybrids in terms of ash content. Regarding feeding values, digestible crude protein (DCP \%) of the tested hybrids ranged from $2.03 \%$ to $4.15 \%$ for TWC 323 and TWC 310 , respectively. The difference in DCP \% may be due to differences in quantity and quality of crude protein in the tested hybrids. Differences among hybrids in total 
digestible nutrient percentages (TDN \%) were not significant. Means of TDN\% ranged from 62.07 to 64.48 for TWC 323 and TWC 320, respectively. Values presented in Table (5) showed significant difference among the tested hybrids in CP, DCP and TDN. TWC 311 was superior in CP, DCP yields, while TWC 324 was the top in TDN yield to the other, recording 564, 276 and $4788 \mathrm{Kg} / \mathrm{fad}$ respectively, TWC 323 had the lowest CP and DCP yield recording 388 and $133 \mathrm{Kg}$ / fad while SC 155 had the lowest TDN (3839 Kg /fad) that showed different ranking among hybrids. Although maize is mainly considered a source of carbohydrate, it is also important protein source because of its considerable total protein yield per faddan, which may produce higher yield potential due to the continued high crop growth rate around flowering (Uribelarrea et al., 2004).

Table 5: Crude protein (CP), digestible crude protein (DCP) and total digestible nutrient $(\mathrm{kg} / \mathrm{fad})$ (TDN) yield in 2006 season .

\begin{tabular}{|c|c|c|c|}
\hline Tyb. & CP kg / fad & DCP kg / fad & TDN kg / fad \\
\hline HYB & 2006 & 2006 & 2006 \\
\hline SC 10 & 524 & 233 & 4662 \\
\hline SC123 & 434 & 182 & 4044 \\
\hline SC155 & 408 & 167 & 3839 \\
\hline TWC310 & 515 & 260 & 3973 \\
\hline TWC311 & 564 & 276 & 4544 \\
\hline TWC320 & 458 & 196 & 4244 \\
\hline TWC321 & 413 & 153 & 4172 \\
\hline TWC322 & 493 & 220 & 4297 \\
\hline TWC323 & 388 & 133 & 4056 \\
\hline TWC324 & 546 & 246 & 4788 \\
\hline Mean & 474 & 207 & 4262 \\
\hline CV \% & 6.1 & 11.6 & 2.8 \\
\hline LSD 0.05 & 65 & 54 & 273 \\
\hline
\end{tabular}

\section{Silage quality}

Concerning silage quality, Table (6) indicated that high quality silage with suitable fermentation characteristics yellowish green colour and good smell was observed. The $\mathrm{PH}$ values of the ten-tested silage samples ranged from 3.6 to 4.05 , which were within the normal range of good quality silage. These results are in agreement with those of Ghanem et al. (2000) who reported $\mathrm{PH}$ values ranging between 3.49 and 3.93 for five hybrids and Bendary et al. (2001) who reported $\mathrm{PH}$ values ranging from 3.74 to 4.18 for 10 hybrids and variety. Lactic acid \% was higher in SC10 and TWC 324, which might be due to the presence of grains. This agreed with Colenbrander et al., (1971), who stated that whole maize plant contains high content of soluble carbohydrates, which are the main source of lactic acid production. Total VFAs concentrations in all kinds of tested silage ranged from 1.46 to $2.44 \%$ of DM, which revealed acceptable silage fermentation. Value of $\mathrm{NH}_{3}-\mathrm{N}$ concentration among silage of the different maize hybrids ranged from 4.08 to 6.88. These results indicated good quality silage as stated by Mc Donaled et al., (1995) who reported that the concentration of $\mathrm{NH}_{3}-\mathrm{N}$ of good quality silage being usually less than $10 \%$ of total $\mathrm{N}$. 
Abdel Gawad, M.A.S. et al.

Table 6: Means of PH, lactic acid \%, VFA \% and NH3.N \% total $\mathrm{N}$ of ten maize hybrids

\begin{tabular}{|c|c|c|c|c|}
\hline Hyb & pH & $\begin{array}{c}\text { Lactic } \\
\text { Acid\% of DM }\end{array}$ & $\begin{array}{c}\text { VFA\% } \\
\text { mol/100ml }\end{array}$ & $\begin{array}{c}\text { NH3.N\% total } \\
\mathbf{N}\end{array}$ \\
\hline SC 10 & 3.84 & 5.28 & 1.72 & 4.51 \\
\hline SC123 & 3.80 & 4.06 & 2.08 & 4.08 \\
\hline SC155 & 4.05 & 3.78 & 2.44 & 6.88 \\
\hline TWC310 & 3.71 & 4.33 & 1.78 & 4.70 \\
\hline TWC311 & 3.60 & 3.82 & 1.46 & 5.17 \\
\hline TWC320 & 3.72 & 4.88 & 1.66 & 4.51 \\
\hline TWC321 & 3.62 & 4.96 & 1.59 & 4.78 \\
\hline TWC322 & 3.68 & 5.10 & 1.80 & 5.22 \\
\hline TWC323 & 3.68 & 4.32 & 1.68 & 4.81 \\
\hline TWC324 & 3.76 & 5.13 & 1.77 & 4.40 \\
\hline mean & 3.74 & 4.56 & 1.8 & 4.84 \\
\hline
\end{tabular}

In conclusion, since all hybrids did not differs significantly in silage quality, therefore the single cross hybrids 10 and 55 as well as the three way cross hybrids $311,321,322,323$ and 324 can be used for silage production based on their superiority in dry silage yield.

\section{REFERENCES}

Allen , Ms; K.A.O Neil; D.G . Main and J. Bec (1990) . Relationship among yield and quality traits of corn hybrids for silage J.Dairy Sci 74 (suppl1 ) :221- 225.

Andrews C.J; L.M. Dwyer; D.W. Stewart; J.A. Dugas, and P.Bonn (2000). Distribution of carbohydrate during grain fill in leafy and normal maize hybrids . Can . J .Plant Sci ( 80 ) 87-95- .

A . O . A . C (1990) : Association of Official Analytical Chemists, Official Methods of Analysis $15^{\text {th }}$ Ed Washington D.C. U.S. A

Bal M.;J.G. Coors. and R. D. Shaver (1997) Impact of the maturity of corn for use as Silage in the diet of dairy cows on intake digestion and milk production J. Dairy Sci.. 80 (10) : 2497-2503.

Bendary M. M ; C. H. A. Chanem ; E. S. Soliman; E. A. Amer and F. A. EL Zeer (2001) Nutritional evaluation of ensiling fresh maze stover . Egyption J. Nutrition and feeds (special issue) 4:105:116.

Church D.C (1979). Livestock feeds and feeding $4^{\text {th }}$ ed D \& B Books, Ine Corvallis, Oreges 97330, U.S.A.

Colenbrnder, V.F;L.D. Muller; J. A. Wasson and Cunningham (1971). Effects of added urea and ammonium polyPHosPHate to corn stover silages on animal performance. J. Anim Sci,5: $1091-1101$.

Dalal R.C. (1989) . Long-term effects of no-tillage, crop residue and nitrogen application on properties of a vertisol soil sci. soc Am.J.: 53 1511-1515

Ghanem,G.H.A; E.A.Amer and F.A.Elzeer (2000).Evaluation using maize stover silage by sheep. J Agric. Tanta university, 26 (4): 591-603

Gomez, K.A. and A.A Gomez (1984) .Statistical procedures for agricultural research. John Wiley and Sons .Inc. New York, USA. 
Kravchenko A.N;G.P. Robertson. K.D. Thelen and R.R. Harwood (2005) : Management topograPHical and weather effects on spatial variability of crop grain yields. Agron. J.97:514-523 .

Kuehn C .S; J .G Linn; D .G. Johnson; H.G.Jung; and M.I. Endres (1999):Effect of feeding silages from corn hybrids selected for leafiness or grain to lactating dairy cattle .J.Dairy Sci 82: 2746-2755.

Ma B. L; K.D. Subedi, D. W. Stewart and L.M. Dwyer (2006): Dry matter accumulation and silage moisture changes after silking in Leafy and dual -Purpose corn hybrids. Agron J 98: 922-929

Mahmoud ,A..M; M.M. Bendary, M.A Harfoush and G.A. Ramadan ( 1992 ) Effect of feeding. Lactating cows corn silage on milk production compared with traditional compared with traditional summer and winter rations . J.Agric . Sci . Mansoura Univ . 17(19):2904

Mc Donald, P;R . A . Edwards; J.F.D Greenhalyh and C.A Morgan (1995) Animal Nutrition $5^{\text {th }}$ Copy right licensing LTD, London .

Mohamed M. M; S . M . M Ahmed and M. M Bendary (1999). Productive and reproductive performance of growing calves fad rations containing maize silage. Egypt. J. Nutr. feeds 2 (special issue) 445-454

MSTAT-C(1986).Amicro computer program for the design, management and analysis of agronomic research experiments. Michigan State Univ. USA

Nofal , F. A. E; G . M . A. Mahgoub, and R . I I .Faisal (2005) : Nitrogen use efficiency of some maize hybrid under different rates of nitrogen fertilizer . Egypt. J. Appl . Sci . 20 (4) : 145-157.

Roth L.S; G.C. Merten W. A Compton D. D. Stuthmann (1970): Genetic variation for quality traits in maize (Zea Maize $L$ ) Forage. Crop Sci. 10: $365-367$.

Sheperd,A.C, and L.Kung, Jr (1996) . Effect of an enzyme additive on compositions of corn silage ensiled at various stages of maturity $\mathrm{J}$.. Dairy. .Sci .79:1767-1773

Uribelarrea M ; F. E. Below and S. P. Moose (2004): Grain composition and productivity of maize hybrids derived from the Illinois protein strains in response to variable nitrogen supply. Crop Sci 44: 1593-1600 .

Wolf D.P;J. G. Coors; K.A.Albreeht; D.J. Undersander and P.R.Carter (1993). For extreme Fiber concentrations. crop Sci. 33: 1353 - 1359.

تقييم · 1 هجن من الذرة الثامية على حاصل السيلاج وجودته 
Abdel Gawad, M.A.S. et al.

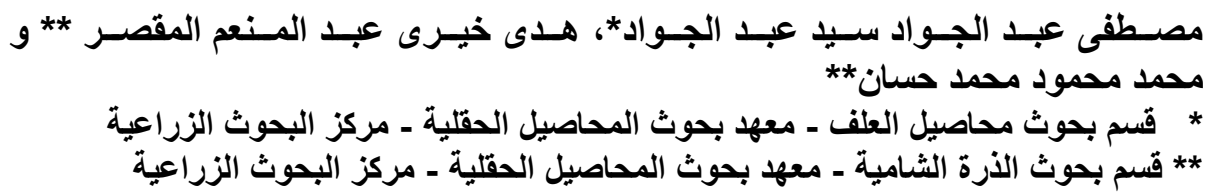

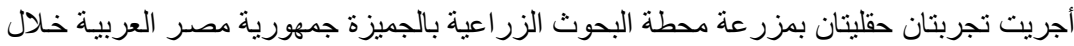

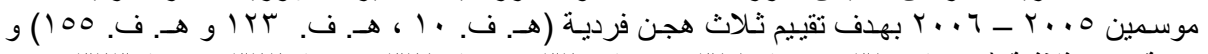

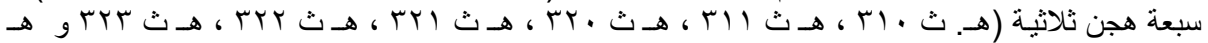

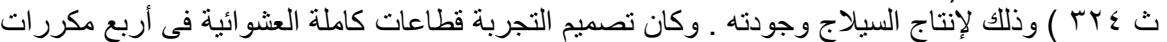

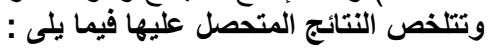

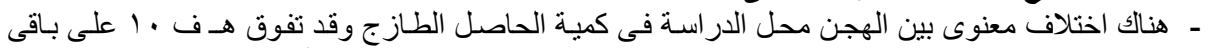

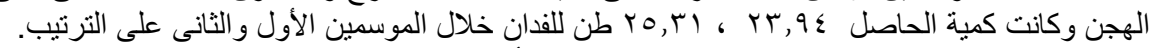

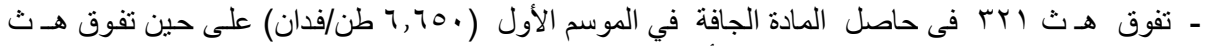

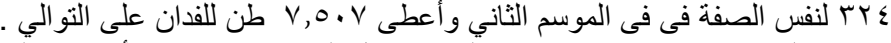

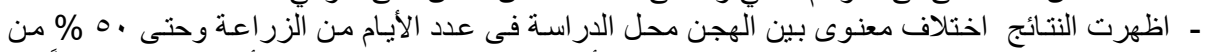

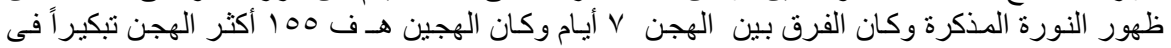

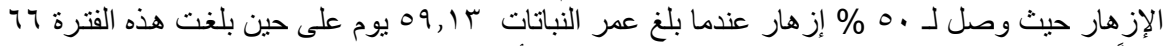

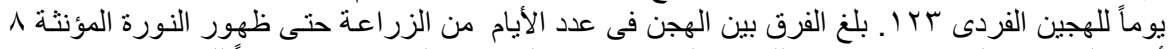

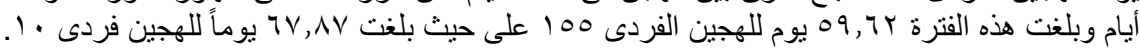

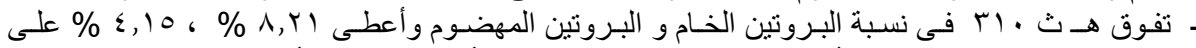

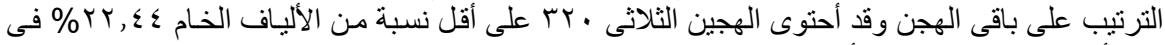

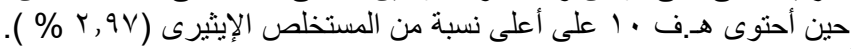

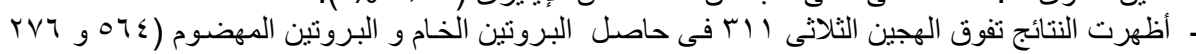

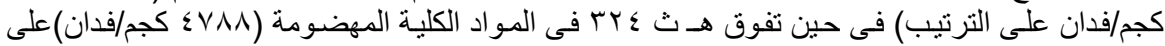
باقى الهجن.

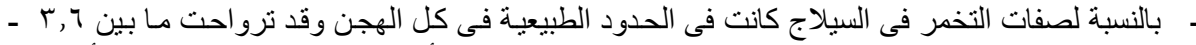

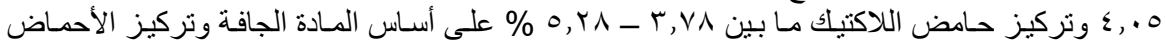

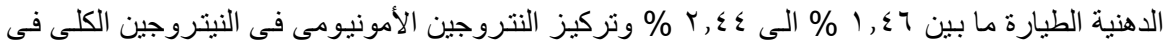

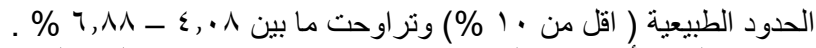

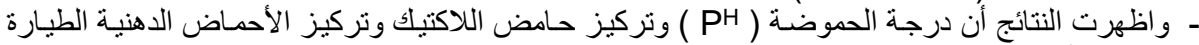
وثركيز أمونيا النتروجين وهى الصفات المعبرة عن جودة السيلاج فى الحدود الطبيعية لجميع الهجن.

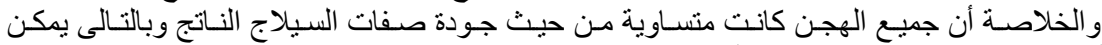

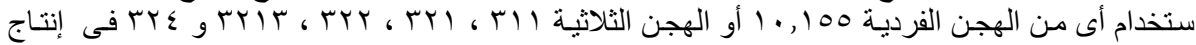

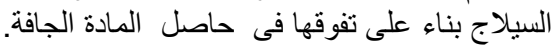


Table 3: Days to $50 \%$ tassling, days to $50 \%$ silking, plant height $(\mathrm{cm})$ and ear height $(\mathrm{cm})$ of maize hybrids at Gemmiza in 2005, 2006 and combined over $2005-2006$ seasons .

\begin{tabular}{|c|c|c|c|c|c|c|c|c|c|c|c|c|}
\hline Character & & $\%$ tassli & & & $\%$ silkin & & Pla & t height ( & m) & & height (c & \\
\hline & 2005 & 2006 & Comb & 2005 & 2006 & Comb & 2005 & 2006 & Comb & 2005 & 2006 & Comb \\
\hline SC 10 & 61.500 & 97.750 & 64.625 & 62.250 & 73.500 & 67.875 & 264.750 & 270.000 & 267.375 & 151.00 & 155.750 & 153.375 \\
\hline SC 123 & 63.250 & 69.000 & 66.125 & 63.750 & 69.000 & 66.375 & 237.250 & 248.500 & 242.875 & 120.00 & 132.500 & 126.250 \\
\hline SC 155 & 56.750 & 61.500 & 59.125 & 57.250 & 62.000 & 59.625 & 224.000 & 247.000 & 235.500 & 130.750 & 144.000 & 137.375 \\
\hline TWC 310 & 61.750 & 64.000 & 62.875 & 62.000 & 64.750 & 63.375 & 263.750 & 266.500 & 265.125 & 157.00 & 157.750 & 157.375 \\
\hline TWC 311 & 61.250 & 63.000 & 62.125 & 62.750 & 63.750 & 63.250 & 241.000 & 246.250 & 243.625 & 141.00 & 152.750 & 146.875 \\
\hline TWC 320 & 62.000 & 64.000 & 63.000 & 63.250 & 65.000 & 64.125 & 255.000 & 273.000 & 264.000 & 144.500 & 159.000 & 151.750 \\
\hline TWC 321 & 62.250 & 63.750 & 63.000 & 60.750 & 65.000 & 62.875 & 243.250 & 266.250 & 254.750 & 140.00 & 146.500 & 143.250 \\
\hline TWC 322 & 59.750 & 62.000 & 60.875 & 60.000 & 63.750 & 61.875 & 264.500 & 272.250 & 268.375 & 155.500 & 153.750 & 154.625 \\
\hline TWC 323 & 60.250 & 64.000 & 62.125 & 60.750 & 64.250 & 62.500 & 251.250 & 268.500 & 259.875 & 142.500 & 151.500 & 147.00 \\
\hline TWC 324 & 61.750 & 63.000 & 62.375 & 62.250 & 65.250 & 63.750 & 252.00 & 273.500 & 262.750 & 133.250 & 159.750 & 146.500 \\
\hline CV\% & 2.07 & 1.53 & 1.80 & 2.07 & 4.79 & 3.77 & 2.79 & 5.13 & 4.18 & 4.44 & 6.80 & 5.825 \\
\hline LSD 0.05 & 1.820 & 1.421 & 1.128 & 1.840 & 4.552 & 2.400 & 10.112 & 19.586 & 10.769 & 9.127 & 14.936 & 8.551 \\
\hline
\end{tabular}

